\title{
A COMPERATIVE STUDY ON MANAGERS' ASSESSMENT OF THE SELECTED PROPERTIES OF INTERNAL REPORTS
}

\section{Justyna Dobroszek}

University of Lodz, Lodz, Poland

e-mail: justyna.dobroszek@uni.lodz.pl

ORCID: 0000-0003-4728-9019

\section{Ewelina Zarzycka}

University of Lodz, Lodz, Poland

e-mail: ezarzycka@uni.lodz.pl

ORCID: 0000-0002-5347-2883

\author{
Alina Almasan \\ West University of Timisoara, Timisoara, Romania \\ e-mail: alina.almasan@e-uvt.ro \\ ORCID: 0000-0002-5416-2465

\section{Cristina Circa} \\ West University of Timisoara, Timisoara, Romania \\ e-mail: cristina.circa@e-uvt.ro
}

ORCID: 0000-0002-5518-9352

(C) 2018 Justyna Dobroszek, Ewelina Zarzycka, Alina Almasan, Cristina Circa

This is an open access article distributed under the Creative Commons Attribution-NonCommercial-NoDerivs license (http://creativecommons.org/licenses/by-nc-nd/3.0/)

DOI: 10.15611/fins.2018.3.04

JEL Classification: M10, M40, M41

\begin{abstract}
An important role in an organization is played by the management information system that enables managers to perform management tasks. The pillar of this system is financial and non-financial data provided by the management accounting system. The effect of the application of specific management accounting tools are various types of studies and analyses, defined in internal reports, which are the basis for management, and thus making decisions by managers. Internal reports, in order to fulfil their functions effectively, must have appropriate features as to its structure, content and other properties. In connection with this, the authors studied and presented an assessment of managers from Poland and Romania in the context of such properties of internal reports as quality, content, presentation and comments. The survey method was used as the research method, while the analysis of collected research material was based on cluster analysis and descriptive statistics. The sample consisted of 154 questionnaires. The findings are similar in both countries, although in the case of Romania, managers who assessed highly the quality and content of internal reports, and evaluated slightly lower the presentations and comments.
\end{abstract}

Keywords: management information system, management accounting system, system, managers, cluster analysis. 


\section{Introduction}

Every organization, in particular that with a complex business profile, needs a proper management system headed by a manager. Its basic part is information, thus creating a Management Information System (MIS). MIS helps enterprises to achieve their goals, plan and control various business processes, moreover it helps reduce the uncertainty of the environment, supports the adjustment of business to changes in its environment, and also affects potential changes. This system may collect information from various areas, e.g. production, logistics, sales and accounting, and this may be information of both a financial and non-financial nature.

An important role in management is played by the information (mainly financial) provided by accounting, usually in the form of financial statements and financial reports. However, it was noted that such data, although significant, are not sufficient for operational and strategic management and for managers at various levels in the organization. The answer to this state of affairs is the Management Accounting System (MAS), which allows measuring business achievements in various perspectives and is directly related to the management process. According to Hilton and Platt [2011], management accounting (MA) is the process of identifying, measuring, analyzing, interpreting and communicating to achieve goals.

MAS fulfils these activities through the implementation of appropriate tools and methods. An important function is fulfilled by the communication of information, which may include the form of information presentation as well as the manner of their transfer. The communication process is defined within the MAS as reporting. Internal reports (i.e. their shape, content, quality and time) and the method of providing information from MAS affect the efficiency of the management process, and thus the decision-making by managers.

The aim of the article is to present an assessment of Polish and Romanian managers in the context of the selected properties of internal reports originating from MAS.

Poland and Romania have been selected for the study because they are examples of large countries from Central and Eastern Europe (CEE), which are characterized by similar cultural, economic and historical conditions. Both countries were influenced by the Soviet Union until 1990. It is worth to point out that at that period the MA could not been officially applied to science and practice in both countries because it was prohibited by the political system. However, after 1990 numerous transformations occurred in various economic and social spheres in Poland and Romania, the most important being the conversion of a planned economy into a market economy, and joining the European Union. At present, the studied countries are developing very dynamically and this has also caused the development of MAS in organizations and their importance for business [Albu, Albu 2012; Lääts, Haldma 2002; Jinga et al. 2010; The growth of Polish and Romanian economies 2018].

The data for the study were collected through a survey carried out among managers from companies in Poland and Romania. To analyse the findings, cluster analysis 
(CA) was used, enabling us to group the collected data according to similarities and thus to present any differences between clusters.

Considering the small number of empirical studies on the managers' assessment of the properties of the internal report as sources of MAS information, especially in scientific publications from CEE countries, the findings of this study may contribute to the existing MA literature.

The paper is divided into six sections. The second section outlines the theoretical framework on MIS and MAS. The third section refers to reporting aspects. The fourth section discusses the research methodology and characterises the research sample. In section five the findings were presented using CA. The final section consists of a discussion and conclusions.

\section{The Management Accounting System (MAS) supporting the Management Information System (MIS)}

MIS is treated as an organisational subsystem providing information which assists operations, management and decision-making in an organisation [Davis, Olsen 1985]. This means that the purpose of MIS is to achieve the goals specified in the given functional area, which impact on the goals of the entire enterprise. Kim [1989] indicates that goals can be expressed in terms of decision-making efficiency, performance, interpersonal relations, job satisfaction etc. Adeoti-Adekeye [1997, p. 325] defined four elements characterising MIS:

- focus on the information designed for the manager in the organisation;

- structural flow of the information;

- data integration as part of the business function in the organisation;

- reporting.

Managers in the organisation need not just raw information, but information that is relevant and current which will contribute to and expand their knowledge, thus reducing uncertainty or ambiguity. Without the relevant information, a manager is unable to perform their function in an organisation efficiently.

MIS is mainly targeted at the user of the information, therefore it is evaluated by the user individually in terms of its effectiveness and usefulness, and the outcome of that evaluation is reflected by the recipient's level of satisfaction see e.g. [Chenhall, Morris 1986; Kim 1989; Goodhue 1998; Pierce, O’Dea 2003; Cheffi, Beldi 2012]. The recipient considers MIS effective if it contributes to improving outcomes (e.g. produces better financial results) and gains relevance in the organisation [Pierce, O'Dea 2003].

Thus far, the discussion on MIS has demonstrated its role in the uncertain and rapidly changing business environment, since the quantity and quality of the information available to a manager can be seen as a driver for the business. As noted by Chong and Eggleton [2003] and Simons [2000], managers who receive the relevant information are able to process it correctly, quickly formulate plans for 
the organisation's future, communicate further steps, identify potential issues, and utilise the available business opportunities more efficiently.

In terms of the application of MIS in the business area of accounting, including management accounting, the literature on the subject highlights the category of Management Accounting System (MAS). Chapman [1998] emphasises that accounting is one of the key sources of information within an organisation.

Mafahr and Omar [Sunarni 2013] stated that MAS is an integral part of the management process in enterprises. It provides important information to the business in the planning, controlling, evaluating and decision-making processes.

The essential role of MAS in an organisation and the importance of its success for business activities are undisputable and are highlighted in a number of studies from around the world (e.g. [Johnson, Kaplan 1987; van der Veeken, Wouters 2002; Szychta 2008; Szychta, Dobroszek 2009; Zarzycka 2016]). Therefore, the studies carried out on the application of MAS by managers seem to be of particular importance. Equally important are the users' evaluation, opinions, satisfaction or dissatisfaction with the use of this system or its elements (e.g. [Almasan et al. 2009; Cheffi, Beldi 2012]).

The essential element of the discussion on MAS is the information characteristics which have a direct effect on the assessment of MAS. Chenhall and Morris [1986] indicate four properties of information influencing the evaluation of managers: scope, timeliness, aggregation and integration. The information scope may be either narrow or broad. The former refers to the economic events occurring within the organisation, and to financial and historical information. The latter, in turn, takes into consideration the external, non-financial and future-oriented information. Delivery of the systematically collected information on time at the request (e.g. of a manager) is referred to as timeliness. Aggregation within MAS takes the form of delivery to managers of the summarised information originating from various time frames and functionalities of the organisation, while integration illustrates the connection of information originating from various segments and functional areas of the given business [Chenhall, Morris 1986]. To support a satisfactory decision-making process, information must be on time, detailed, complete and relevant [Mendoza, Bescos, 2001]. The fact that the reports generated by MAS are incomprehensive, unclear and excessively standardised is also harmful to the process of providing informational support for decision-making [Stocks, Harrell 1995]. The customisation of the reports and their adjustment to the informational needs of particular users is a viable solution [Shields 1997]. Moreover, managers would like information to be transmitted in a better, more modern format. The managers surveyed by Pierce and O'Dea [2003] pointed to graphic representation as one of the most unsatisfactory elements of the reports prepared by management accounting departments. Finally, information in reports should be accompanied by useful comments provided by management accountants [Dempsey, Vance 2006] and contain references to the future [Johnson, Kaplan 1987]. 
Taking into account the importance of the presentation of information from MAS and the form of its delivery for managers, the next item of this paper will be devoted to the issue of the internal reporting process.

\section{Reporting as a process providing the MAS information to managers}

As described by Nita [2014], the effect of using specific MAS methods and tools are various types of analyzes, studies and simulations. These elements are described in MAS as internal reports, and they are the result of the reporting process. Reporting includes data collection, documenting, processing and its presentation in an appropriate form. This means that the data properly calculated and ordered are collected in one whole, i.e. in the form of internal reports and in this way the managers have access to important values and any arising deviations in individual business areas of the organization.

Nita [2009, p. 293] also indicates that internal reporting includes three pillars: flow of management information, scope of internal reporting and organization of internal reporting. Taking into account the issue undertaken in the paper, the third pillar seems to be the most important to it. The organization of reporting consists in the assignment of persons responsible for preparing reports according to established structures with specific features and their frequency of creation and delivery [Nita 2009].

The essence in preparing internal reports is attributed to the volumes and results from bookkeeping and cost accounting. Internal reports are to meet the expectations of their recipients, i.e. managers in the field of decision-making, and thus also planning and control, mainly in the short-term perspective which, however, has its impact on the long-term perspective. Therefore, monthly, quarterly and annual reports are listed which present current data, deviations and comments in a transparent manner [Jung 2007].

Internal reports are characterized by various cross-sections, i.e. temporal, objective or subjective. They may contain various objects of calculations and its profitability evaluation (e.g. products, services, clients etc.), data from different time periods (historical data, actual and forecasted for the future) as well as deviations with comments explaining their causes.

Internal reports, and thus reporting, is related to the process of measuring achievements, so it includes financial and non-financial information as well as internal and external information [Nita 2013]. However, it is worth noting that the quality of information is important, and not just the quantity, so it is necessary to ensure their transparency with regard to finances, liquidity, sales situation, costs and results, as well as human resources, organization and logistics structures etc.

When creating internal reports, many factors should be taken into account, in particular the recipient and his/her information needs for the implementation of his/ 
her tasks related to planning, control and decision making. According to Jung [2007] a correctly prepared internal report is a form of database, a means of improving communication in the organization, ensures better controls and a set of final analyzes in various areas. The same author [Jung 2007] highlights the four main features of internal reports, which can be evaluated by their recipients (managers), which are: data consistency, transparency, reduction of complexity and visual aspects.

Waniczek [2002] characterised two specific elements of internal reports, i.e. formal and informal elements. The formal elements refer primarily to the content, where a report should contain the planned data (What do we want to achieve?), actual data (Where are we now?), analysis of deviations (Why did we exceed the objective?), and directions for the future (comment) (What do we do next?).

The information base for the preparation of internal reports is data on the one hand generated obligatorily from the point of view of financial reporting (costs, revenues, results), and on the other hand data created voluntarily in MAS (profitability, nonfinancial data as time). Therefore it is possible to show the interlocking of both systems in an enterprise [Sobańska 2012]. Moreover, information created in MAS (internal data) is increasingly used in financial reports made available to the environment outside [Nita 2013].

Considering that internal reports are part of MIS, and therefore the appropriate organization of reporting is important for the proper management process in an organization, the next part of the article will present the findings of our own empirical study presenting managers' assessments in the context of the discussed issues.

\section{Research Methodology and Sample}

The research data was collected as a result of an empirical study in the form of a survey, conducted between May 2015 and March 2016, based on selected businesses across various industries operating in Poland and Romania and characterised by the different origins of their founding capital. The questionnaire was sent to managers (mainly operations managers) of surveyed companies from Poland and Romania. We sent an online survey to over 300 enterprises (200 from the former and 100 from the latter) of various sizes (though primarily medium and large organizations) from different industries. The unequal number of surveys in these countries results from the better access of researchers from Poland than from Romania to the companies' databases. The analysis of the collected questionnaires showed that 154 were completed correctly, providing high-quality data. Out of the 154 questionnaires, 116 originated from Poland and 38 from Romania.

The questionnaire consisted of 26 half-open and closed questions (single and multiple-choice, span and matrix), structured in four different sections: two of them regarded the characterization of the company and respondents, the third section was related to the existence and form of the management accounting system within the 
companies, while the fourth section regarded the perception of the managers on the suitability of the information delivered by management accounting (MA) systems.

In order to thoroughly analyse the set of data obtained from the conducted survey, CA was applied. This method allows for the segregation of the observed data into specific groups so that the degree of association of certain objects with others belonging to the same group is as high as possible, while the association with objects from other groups is as low as possible. This tool systematises to a large extent the gathered information into specific structures and, consequently, gives an overview of the surveyed objects.

In addition to CA, descriptive statistics (the frequency of occurrence of phenomenon, mean standard deviation, variance) were used in the presentation of the findings.

For the purpose of CA, a classification based on the variables with the use of the agglomerative (hierarchical) method was made in which Euclidean distance was applied in order to calculate the distance between objects, and Ward's method, considered one of the most efficient, as a method to combine the objects and classes [Online Manual on Statistics 2017]. In this way, the variables were divided into pairs or larger groups (agglomerations, clusters) most similar to each other. The next step in CA consisted in grouping the data according to objects (respondents) using the $\mathrm{k}$-means method, which allows the creation of a number of clusters. It was expected that the respondents would be divided into three groups.

The Polish and Romanian companies involved in the study were mainly manufacturing enterprises (52\%, 61\% respectively). About $30 \%$ of the companies from both countries were service providers while slightly over $10 \%$ were trade companies. Over $60 \%$ of the surveyed companies could be classified as large in terms of their number of employees. The majority of these companies had foreign capital: $42 \%, 57 \%$ respectively of the studied population.

The educational level of the surveyed managers should be pointed out; $98 \%$ of the Polish managers hold a Master's degree, $40 \%$ an MBA and $9 \%$ a PhD, while $68 \%$ of the Romanian managers hold a Master's degree with only 13\% an MBA.

\section{Presentation of findings}

The agglomerative method for the variables was also used for the CA in respect of the assessment of the properties of internal reports received from the MAS. The following variables were taken into account: quality, content, presentation of data, and comments.

After the first stage of clustering, two main clusters were formed: quality and content (cluster 1) and presentation of data and comments (cluster 2). The first cluster is composed of quality and substantive aspects, since the accuracy and the appropriate selection of data is reflected in the quality of the reports. Whereas the second cluster is formed by visual and explanatory aspects, which create added value 
to internal reports, facilitating their reading by managers and supporting them in the process of the ongoing assessment of the business situation and decision-making (see Figure 1).

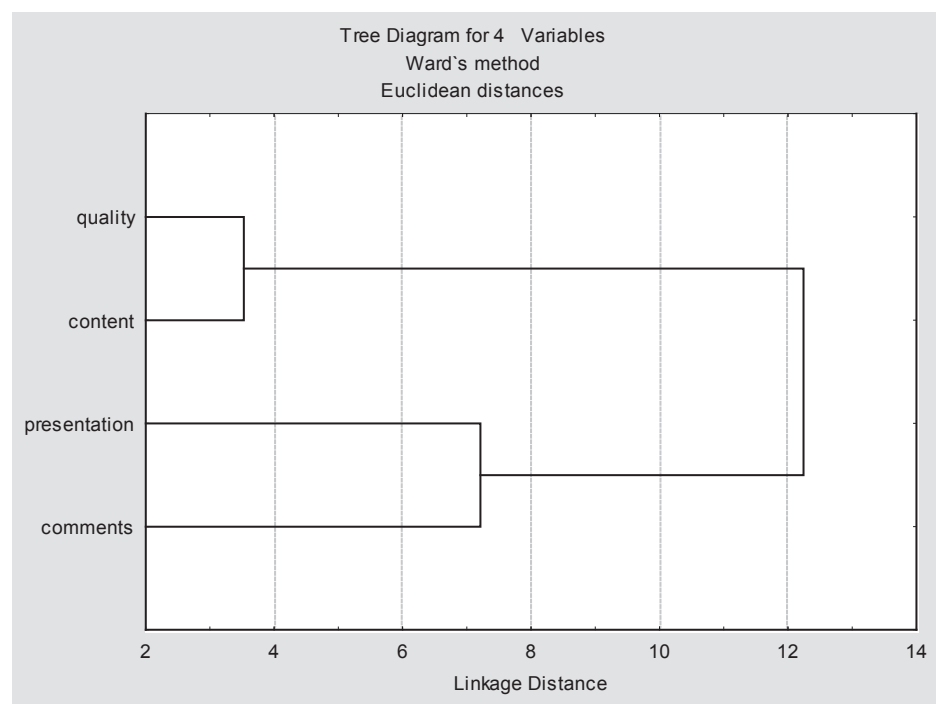

Fig. 1. A dendrogram containing the results of the assessment made by the managers in Poland in terms of the properties of internal reports received

Source: own elaboration.

The Figure above confirms that the assessments of managers in respect of such elements as quality and content are similar. Similar findings were obtained in the case of the assessment of the properties of the reports such as presentation and comments. This means that if the managers evaluated highly the quality, they also evaluated highly the content of the reports, whereas in the second group, if the managers evaluated highly the presentation of data (form), they also evaluated highly the comments contained in internal reports.

The higher level of aggregation may suggest a division of the managers into two homogeneous groups, i.e. the first group of managers who evaluate the quality and content of the reports highly, and the second group of managers who evaluate highly the presentation of data and comments. At this point, it is possible to divide the surveyed managers into those who put an emphasis on the traditional aspects of reports, i.e. their appropriate content and quality, thus calling them "traditional managers", and the managers for whom the proper form of presentation (e.g. graphs) and comments are essential, therefore they can be called "modern managers". The authors introduced such a division to make it clear that quality and content are the basic properties of all types of reports (even financial reports), while presentation 
and comments create added value for reports, and should occur in reports for internal purposes in organizations.

The above conclusions are complemented with the result of the grouping of the objects (respondents) with the k-means method (where $k=3$ ), as shown in Figure 2.

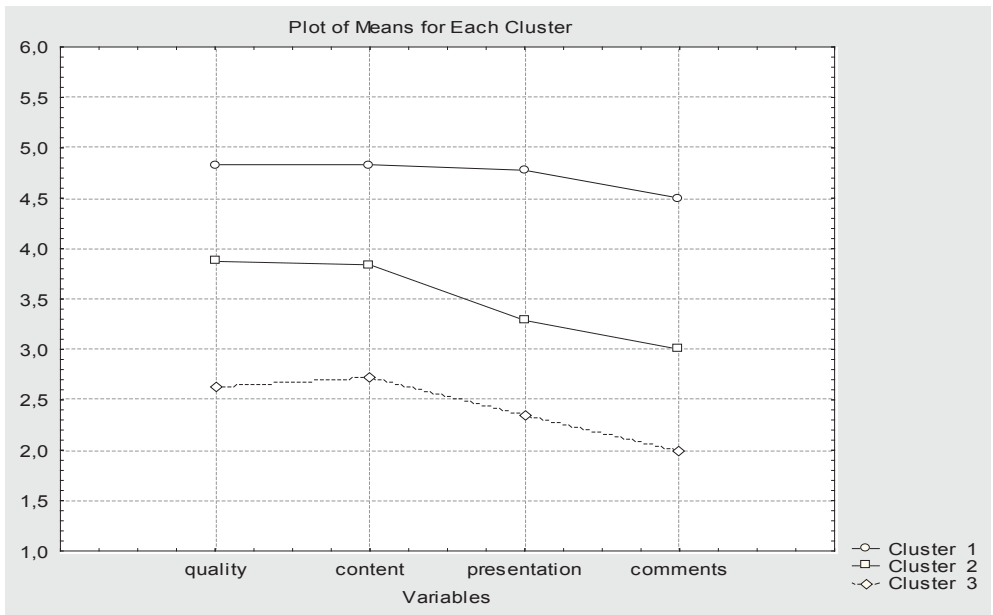

Fig. 2. The results of grouping of the managers with the k-means method in the context of the assessment made by the managers from Poland of the elements of internal reports

Source: own elaboration.

The division into three clusters indicates an arrangement of the managers into those who evaluate the properties of internal reports for the performance of the indicated activities under the management process as low, moderate, and high. They can be divided into the so-called sceptics, neutral, and supporters. It should also be noted that the three clusters differ in terms of the average assessments of all tools.

Accurate information on the differences in the average answers of the three groups seen on the attached graph are presented in Table 1. It is worth noting that the size of group 2 (58 respondents), making a moderate evaluation of the elements of internal reports, differs significantly from the sizes of cluster 1 (12 respondents) and 3 (22 respondents). This means that in the majority of cases, the managers from the examined companies operating in Poland evaluated the analysed elements of internal reports as neither high nor low.

The same scope of analysis was prepared in the context of assessments of managers operating in studied companies from Romania.

After the first stage of clustering, two main clusters were formed, i.e. quality and content (cluster 1) and presentation of data and comments (cluster 2). This means that the first cluster is composed of quality and substantive aspects, while the second is formed by visual and explanatory aspects. The level of agglomeration is presented in Figure 3. 
Table 1. Answers of the groups (clusters) from Poland making a higher, moderate and lower average assessment of the properties of internal reports provided by the MAS

\begin{tabular}{|l|c|c|c|}
\hline \multicolumn{4}{|c|}{ Descriptive Statistics for Cluster 1 (Cluster contains 12 cases) } \\
\hline $\begin{array}{c}\text { Elements } \\
\text { of internal reports }\end{array}$ & Mean & Standard - Deviation & Variance \\
\hline quality & 4.833333 & 0.174078 & 0.030303 \\
\hline content & 4.833333 & 0.174078 & 0.030303 \\
\hline presentation & 4.777778 & 0.259500 & 0.067340 \\
\hline comments & 4.500000 & 0.522233 & 0.272727 \\
\hline \multicolumn{5}{|c|}{ Descriptive Statistics for Cluster 2 (Cluster contains 58 cases) } \\
\hline quality & 3.873563 & 0.398964 & 0.159172 \\
\hline content & 3.839081 & 0.480584 & 0.230961 \\
\hline presentation & 3.287356 & 0.447859 & 0.200578 \\
\hline comments & 3.000000 & 0.675382 & 0.45614 \\
\hline \multicolumn{5}{|c|}{ Descriptive Statistics for Cluster 3 (Cluster contains 22 cases) } \\
\hline quality & 2.636364 & 0.571909 & 0.327080 \\
\hline content & 2.727273 & 0.500120 & 0.250120 \\
\hline presentation & 2.333333 & 0.617213 & 0.380952 \\
\hline comments & 2.000000 & 0.617213 & 0.380952 \\
\hline
\end{tabular}

Source: own elaboration.

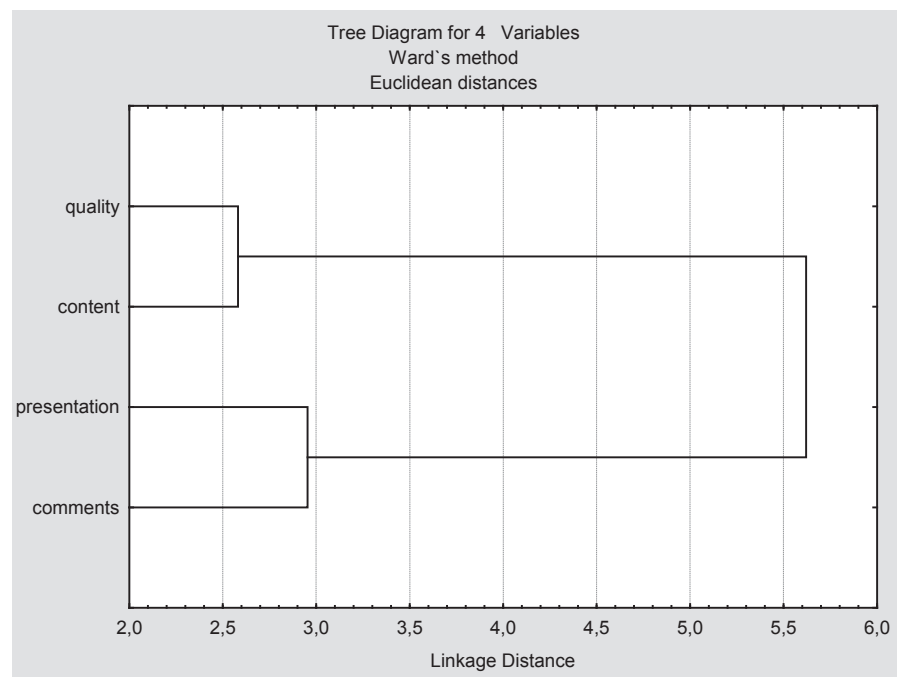

Fig. 3. A dendrogram containing the results of the assessment made by the managers from Romania in terms of the properties of internal reports

Source: own elaboration. 
The above conclusions are complemented with the result of the grouping of the objects (respondents) with the $k$-means method (where $k=3$ ), as shown in Figure 4.

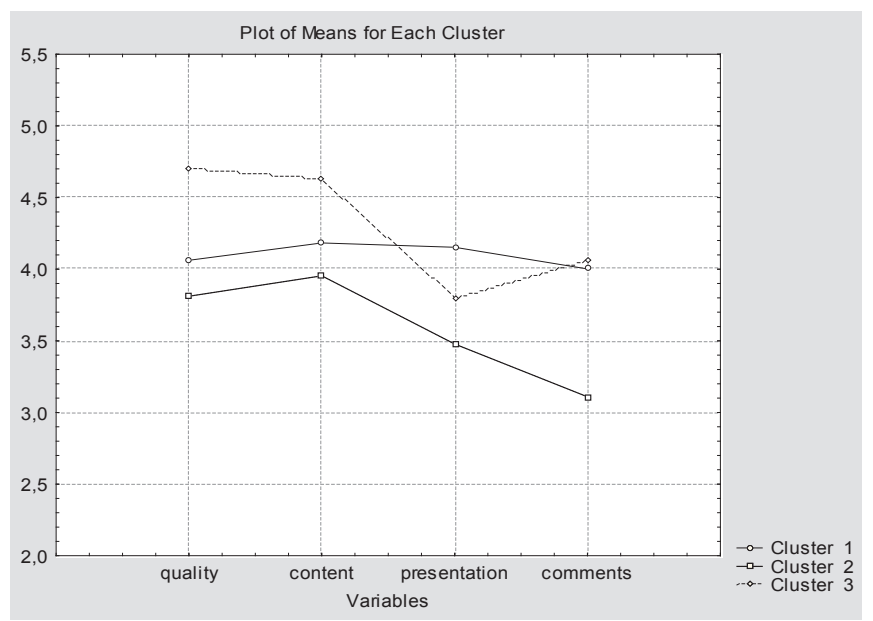

Fig. 4. The results of the grouping of the managers with the k-means method in the context of the assessment made by managers from Romania of the elements of internal reports

Source: own elaboration.

In the division into three clusters there is a noticeable arrangement of the managers who evaluate the elements of internal reports provided by the MAS for the performance of management activities as low, moderate, and high. It also needs to be stressed that the three clusters differ in terms of the average assessments of all the studied elements. The studied managers from cluster 3 who evaluated the quality and content of the reports as high, evaluated the form of presentation of data in internal reports lower than the respondents from cluster 1 and the comments at a similar level than the respondents from cluster 1 . Table 2 contains the information on the differences in the average answers of these three groups visible in the attached graph. It is worth noting that the sizes of the groups were similar $(11,14,8$ respondents, respectively).

Table 2. Answers of the groups (clusters) from Romania making a higher, moderate and lower average assessment of the properties of internal reports provided by the MAS

\begin{tabular}{|c|c|c|c|}
\hline \multicolumn{4}{|c|}{ Descriptive Statistics for Cluster 3 (Cluster contains 8 cases) } \\
\hline $\begin{array}{c}\text { Elements } \\
\text { of internal reports }\end{array}$ & Mean & Standard - Deviation & Variance \\
\hline 1 & 2 & 3 & 4 \\
\hline quality & 4.708333 & 0.213623 & 0.045635 \\
\hline content & 4.625000 & 0.278174 & 0.077381 \\
\hline
\end{tabular}




\begin{tabular}{|l|c|c|c|}
\hline \multicolumn{1}{|c|}{1} & 2 & 3 & 4 \\
\hline presentation & 3.791667 & 0.434157 & 0.188492 \\
\hline comments & 4.062500 & 0.320435 & 0.102679 \\
\hline \multicolumn{4}{|c|}{ Descriptive Statistics for Cluster 1 (Cluster contains 11 cases) } \\
\hline quality & 4.060606 & 0.250252 & 0.062626 \\
\hline content & 4.181818 & 0.456159 & 0.208081 \\
\hline presentation & 4151515 & 0.273400 & 0.074747 \\
\hline comments & 4.000000 & 0.316228 & 0.100000 \\
\hline \multicolumn{4}{|l|}{ Descriptiven } \\
\hline quality & 3.809524 & 0.466195 & 0.217338 \\
\hline content & 3.952381 & 0.389107 & 0.151404 \\
\hline presentation & 3.476191 & 0.283877 & 0.080586 \\
\hline comments & 3.107143 & 0.349647 & 0.122253 \\
\hline
\end{tabular}

Source: own elaboration.

\section{Conclusion and discussion}

The agglomerative method enabled the detection for Poland and Romania of the same clusters at the lower and higher level of the agglomeration. However, the analysis with the use of the k-means method showed a slightly different overview of data verification for both countries, mainly in the case of the respondents assessing the analysed properties of the internal reports highly and moderately. For the managers of the examined companies in Poland an organised arrangement of clusters can be seen, i.e. the respondents who evaluated highly e.g. quality evaluated highly also the content, presentation of data, and comments. The same situation occurs for the managers who evaluate moderately and sceptically the analysed properties of internal reports.

In the case of Romania, the respondents who evaluated highly the quality and content of internal reports, evaluated the presentation of data (form) lower than the respondents with a moderate approach to the assessment. This may mean that in the case of Romania, high assessments relate to the content and the quality of internal reports, while the other properties are evaluated as moderate or low.

The CA indicates that the managers in both countries evaluated as high the content of the reports for the purposes of their performance of the management's tasks. However, the managers from Romania evaluated the comments slightly lower than in the case of the managers from Poland. This may be due to various factors, e.g. less developed MAS in the organizations operating in Romania than in Poland, or the sufficient satisfaction of Romanian managers with the basic properties of the reports, i.e. content (Tables with financial data). 
Considering the findings presented, on the one hand, we recognized some similarities in the evaluations of Polish and Romanian managers of selected properties of internal reports, on the other hand, there are some differences. However, the reporting process and the elements of reports are of great importance for the work of managers, since they contain key information to support the management process and, therefore, decision-making. As stated by other researchers, e.g. Dempsey and Vance [2006] and Pierce and O'Dea [2003], managers need internal reports that, apart from the usual data content in the form of tables and numbers, they contain new forms of data presentation (e.g. more charts) and additional comments. This means that internal reports are better perceived by managers because they provide additional information value that may be translated into their work.

The internal reports may differ in terms of the form, content, and presentation of data between companies. However, as indicated by Preißler [1997, p. 123] reports should be brief, specific, and useful for the assessment of business and decisionmaking, and also adjusted to the relevant group of recipients, i.e. managers.

The conducted study has some limitations, such as small research sample, in particular in the case of Romania, the form of research method used, i.e. the questionnaire survey, and the identification of the very general properties of internal reports for assessment by Polish and Romanian managers. One direction for further research should include the accurate verification of the needs of managers in the scope of reports and their properties, and how these properties may be translated into specific tasks within management and decision-making considering e.g. the size of the enterprises and their scope of business activity, MAS organization, the experience of the managers and the area of management in the company.

\section{Bibliography}

Adeoti\&Adekeye W.B., 1997, The importance of management information systems, Library, vol. 46, no. 5 , pp. 318-327.

Albu C.N., Albu N., 2012, Factors associated with the adoption and use of management accounting techniques in developing countries: the case of Romania, Journal of International Financial Management \& Accounting, vol. 23, no. 3, pp. 50-69.

Almasan A., Grosu C., 2009, The usefulness of the process approach for value creation in the telecom sector, Journal of Accounting and Management Information Systems, vol. 8, no. 4, pp. 521-537.

Cheffi W., Beldi A., 2012, Analysis of managers'use of management accounting, International Journal of Business, vol. 17, no. 2, pp. 113-125.

Chapman C.S., 1998, Accountants in organisational networks, Accounting, Organizations and Society, 23 (8), pp. 737-766.

Chenhall R.H., Morris D., 1986, The impact of structure, environment, and interdependence on the perceived usefulness of management accounting systems, The Accounting Review, vol. 61, no. 1, pp. 16-35.

Chong V.K., Eggleton, I.R.C., 2003, The decision-facilitating role of management accounting systems on managerial performance: the influence of locus of control and task uncertainty, Advances in Accounting, vol. 20, pp. 165-97. 
Davis G.B., Olson M.H., 1985, Management Information Systems: Conceptual Foundations, Structure, and Development, McGraw-Hall, Singapore.

Dempsey S., Vance, R., 2006, Management accountants: leading the agenda, not just supporting it, Accountancy Ireland, vol. 38, no. 6, pp. 13-16.

Goodhue D.L., 1998, Development and measurement validity of a task-technology fit instrument for user evaluations of information systems, Decision Sciences, vol. 29, no. 1, pp. 105-138.

Jinga G., Dumitru M., Dumitrana M., Vulpoi, M., 2010, Accounting systems for cost management used in the Romanian economic entities, Journal of Accounting and Management Information Systems, vol. 9 , no. 2 , pp. 242-267.

Johnson H.T., Kaplan R., 1987, Relevance Lost: The Rise and Fall of Management Accounting, Harvard Business School Press, Boston, MA.

Jung H., 2007, Controlling, 2. Aufl., München.

Kim K.K., 1989, User satisfaction: a synthesis of three different perspectives, Journal of Information Systems, Fall, pp. 1-12.

Lääts K., Haldma T., 2002, Contingencies influencing the management accounting practices in estonian manufacturing companies, Management Accounting Research, vol. 13 no. 4, pp. 379-400.

Mendoza C., Bescos P.L., 2001, An explanatory model of managers' information needs: implications for management accounting, The European Accounting Review, vol. 10, no. 2, pp. 257-289.

Nita B., 2014, Zakres wewnętrznych analiz dotyczacych rentowności w controllingu operacyjnym, Zeszyty Naukowe Uniwersytetu Szczecińskiego, nr 803, Finanse, Rynki Finansowe, Ubezpieczenia, nr 66, pp. 75-86.

Nita B., 2013, Raportowanie wewnętrzne w zakresie jakości, Zeszyty Naukowe Uniwersytetu Szczecińskiego, nr 803, Finanse, Rynki Finansowe, Ubezpieczenia, nr 58, pp. 253-260.

Nita B., 2009, Rola rachunkowości zarządczej we wspomaganiu zarządzania dokonaniami przedsiębiorstwa, Wydawnictwo Uniwersytetu Ekonomicznego we Wrocławiu, Wrocław.

Online Manual on Statistics, 2017, StatSoft Electronic Statistics Textbook, http://www.statsoft.com/ Textbook (access: 28.12.2017).

Pierce B., O'Dea T., 2003, Management accounting information and the needs of managers: perceptions of managers and accountants compared, The British Accounting Review, vol. 35, no. 3, pp. 257-90.

Preißler P., 1997, Controlling, Oldenbourg, München.

Shields M.D., 1997, Research in management accounting by North Americans in the 1990's, Journal of Management Accounting Research, vol. 9, pp. 3-61.

Simons R., 2000, Performance Measurement and Control Systems for Implementing Strategy: Text and Cases, Prentice-Hall, Upper Saddle River, NJ.

Sobańska I., 2012, Jedność system rachunkowości, Zeszyty Teoretyczne Rachunkowości, 66(122), pp. 179-189.

Stocks M.H., Harrell A., 1995, The impact of an increase in accounting information level on the judgement quality of individuals and groups, Accounting, Organizations and Society, vol. 20, no. 7-8, pp. 685-700.

Sunarni C.W., 2013, Management Accounting Practices and the Role of Management Accountant: Evidence from Manufacturing Companies throughout Yogyakarta, Review of Integrative Business \& Economics, vol. 2(2), pp. 616-626.

Szychta A., 2008, Etapy ewolucji i kierunki integracji metod rachunkowości zarzadczej, Wydawnictwo UŁ, Łódź. Jedność systemu rachunkowości, Zeszyty Teoretyczne Rachunkowości, nr 66(122), pp. 179-190.

Szychta A., Dobroszek J., 2009, Koncepcyjny i ewolucyjny wymiar controllingu, Zeszyty Teoretyczne Rachunkowości, vol. 128, no. 52, pp. 21-48.

The growth of the Polish economy, https://www.money.pl/gospodarka/wiadomosci/artykul/pkb-polskiwzrost-gospodarczy-gus-trzeci,181,0,2392245.html, access: 30.03.2018. 
The growth of the Romanian economy, https://businessinsider.com.p1/finanse/makroekonomia/wzrostpkb-w-rumunii-w-iii-kw-2017-r/ge5wsz0, access: 30.03.2018.

Waniczek A., 2002, Berichtswesen optimieren: So steigern Sie die Effizienz in Reporting und Controlling, Redline Verlag, Norderstedt.

van der Veeken, H.J.M., Wouters, M.J.F. ,2002, Using accounting information systems by operations managers in a project company, Management Accounting Research, vol. 13, pp. 345-70.

Zarzycka E., 2016, Koncepcje i tendencje rozwoju zawodu specjalisty rachunkowości zarzadczej. Wymiar krajowy i międzynarodowy, Wydawnictwo Uniwersytetu Łódzkiego, Łódź.

\section{BADANIE PORÓWNAWCZE W ZAKRESIE OCENY WYBRANYCH WLAŚCIWOŚCI RAPORTÓW WEWNĘTRZNYCH PRZEZ MENEDŻERÓW}

Streszczenie: Istotną rolę w organizacji odgrywa system informacji zarządczej, który umożliwia menedżerom realizację zadań związanych z zarządzaniem. Filarem tego systemu są dane finansowe i niefinansowe dostarczane przez system rachunkowości zarządczej. Efektem zastosowania określonych narzędzi rachunkowości zarządczej są różnego rodzaju opracowania i analizy, nazywane raportami wewnętrznymi, które są podstawą zarządzania, a więc podejmowania decyzji przez menedżerów. Raporty wewnętrzne, aby wypełniały skutecznie swoje funkcje, muszą mieć odpowiednie cechy dotyczące struktury, zawartości i innych elementów. Autorzy zbadali oraz przedstawili oceny menedżerów z Polski i Rumunii w zakresie takich właściwości raportów wewnętrznych, jak: jakość, zawartość, komentarze i prezentacja. Jako metodę badawczą zastosowano badanie ankietowe, do analizy zaś zebranego materiału badawczego wykorzystano analizę skupień i statystykę opisową. Próba badawcza objęła 154 respondentów. Uzyskane wyniki są zbliżone w obu krajach, choć w przypadku Rumunii menedżerowie, którzy ocenili wysoko jakość i zawartość raportów wewnętrznych, nieco niżej ocenili prezentacje i komentarze.

Słowa kluczowe: system informacji zarządczej, system rachunkowości zarządczej, wewnętrzne raporty, menedżer, analiza skupień. 